\title{
GENETIC VARIATION AMONG AND WITHIN PROVENANCES AND PROGENIES OF Corymbia maculata (Hook.) K. D. Hill and L. A. S. Johnson, IN PEDERNEIRAS, SP
}

\author{
Aida Sanae Sato', Miguel Luiz Menezes Freitas², Israel Luiz de Lima³, Léo Zimback4, \\ Maria Teresa Zugliani Toniato ${ }^{5}$, Alexandre Magno Sebbenn ${ }^{6}$
}

(received: May 21, 2009; accepted: December 21, 2009)

\begin{abstract}
This study aimed to estimate genetic parameters and variation in a provenance-progeny test of $C$. maculata (ex Eucalyptus maculata Hook.), conducted at Pederneiras Experimental Station, in São Paulo Forest Institute. The test was based on 21 open-pollination progenies from provenance Woondum St. Forest and 17 from provenance Wondai St. Forest, both in Australia. A compact family block design was adopted consisting of ten blocks, six plants per straight-line plot and two outer border rows, with spacing $3 \times 2 \mathrm{~m}$. Traits assessed included diameter at breast height (DBH), height, volume, form and survival rate at age 4 and 21 years. Significant differences were detected only at age 4 between provenances for DBH and height and among progenies for DBH, height and volume. The coefficient of genetic variation was higher for all traits at age 21 . The heritability coefficient at the progeny level $\left(h_{m}^{2}\right)$ was also higher at age 21 and ranged from 0.21 for volume to 0.40 for height, indicating that genetic progress can be achieved through selection of the best progenies. Genetic correlations were high between traits within and between age categories, showing that potential genetic gains can be achieved through indirect, early selection. Results indicate that considerable gains can be made if high selection intensity is applied among and within progenies, with values ranging from $12.48 \%$ for height to $21.77 \%$ for volume.
\end{abstract}

Key words: Forest improvement, genetic variability, genetic selection, quantitative genetics.

\section{VARIAÇÃo GENÉTICA ENTRE E DENTRO DE PROCEDÊNCIAS E PROGÊNIES DE Corymbia maculata (Hook.) K. D. Hill and L. A. S. Johnson, EM PEDERNEIRAS, SP}

RESUMO: Conduziu-se este estudo, com o objetivo de estimar a variação e parâmetros genéticos em um teste de procedências e progênies de C. maculata (ex Eucalyptus maculata Hook.), implantado na Estação Experimental de Pederneiras, Instituto Florestal de São Paulo. O teste foi implantado com 21 progênies de polinização aberta da procedência Woondum St. Forest e 17 da Wondai St. Forest, ambas da Austrália. O delineamento experimental adotado foi o de blocos de famílias compactas, com dez blocos, parcelas lineares de seis plantas e duas linhas de bordadura externa, no espaçamento $3 \times 2 \mathrm{~m}$. Foram avaliados os caracteres diâmetro a altura do peito (DAP), altura, volume, forma e sobrevivência aos quatro e 21 anos de idade. Foram detectadas diferenças significativas apenas aos quatro anos entre procedências para DAP e altura e entre progênies para DAP, altura e volume. O coeficiente de variação genética foi maior para todos os caracteres na idade de 21 anos. O coeficiente de herdabilidade em nível de progênies $\left(h_{m}^{2}\right)$ também foi superior aos 21 anos e variou de 0,21 para volume a 0,40 para altura, indicando que o progresso genético pode ser obtido pela seleção das melhores progênies. As correlações genéticas foram altas entre os caracteres, nas mesmas e diferentes idades, o que mostra a possibilidade de se obterem ganhos genéticos pela seleção indireta e precoce. Os resultados indicaram que altos ganhos podem ser obtidos se uma alta intensidade de seleção for aplicada entre e dentro de progênies, com valores variando de 12,48 \% para altura a 21,77\% para volume.

Palavras-chave: Melhoramento florestal, variabilidade genética, seleção genética, genética quantitativa.

\section{INTRODUCTION}

Corymbia maculata Hook (ex Eucalyptus maculata Hook.) is a species of the greatest commercial importance for the Australian timber industry, with extensive areas of the country being cultivated with the crop, despite its susceptibility to fungus rust caused by Ramularia pitereka (SELF et al. 2002). C. maculata naturally occurs at latitudes

${ }^{1}$ Forest Engineer, Researcher - Instituto Florestal - Divisão de Dasonomia - Seção de Melhoramento Florestal - Rua do Horto, 931 Cx. P. 1322 - 01059-970 - São Paulo, SP, Brazil - aidasato@if.sp.gov.br

${ }^{2}$ Agronomic Engineer, Senior Researcher at the Instituto Florestal - Cx. P. 1322 - 01059-970 - São Paulo, SP, Brazil miguellmfreitas@yahoo.com.br

${ }^{3}$ Forest Engineer, Senior Researcher at the Instituto Florestal - Cx P. 1322 - 01059-970 - São Paulo, SP, Brazil israelluizde.lima@yahoo.com.br

${ }^{4}$ Agronomic Engineer, Senior Researcher at the Instituto Florestal - Cx. P. 78 - 18701-180 - Avaré, Brazil - 1zimback@ terra.com.br ${ }^{5}$ Biologist, Senior Researcher at the Instituto Florestal - Estação Experimental de Bauru - Av. Rodrigues Alves, 38-25 - 17030-000 Bauru, SP, Brazil - mate_zt @yahoo.com.br

${ }^{6}$ Forest Engineer, Senior Researcher at the Instituto Florestal - Cx. P. 1322 - 0159-970 - São Paulo, SP, Brazil alexandresebbenn@yahoo.com.br

Cerne, Lavras, v. 16, n. 1, p. 60-67, jan./mar. 2010 
$25^{\circ}$ to $37^{\circ} \mathrm{S}$ (Queensland and New South Wales States, Australia), at altitudes that can range from sea level to $800 \mathrm{~m}$, where average annual precipitation ranges from 625 to 1,250 mm (FERREIRA 1979). When young the above species does not tolerate severe frost (LORENZI et al. 2003, ROB 2004), developing best in well drained soils of moderately heavy texture and potentially reaching 45 to $50 \mathrm{~cm}$ of $\mathrm{DBH}$ in a span of 20 to 25 years (ROB 2004). Its high-density wood $\left(>600 \mathrm{Kg} / \mathrm{m}^{3}\right)$ (PEREIRA et al. 2000) with excellent structural properties makes it a very popular choice for woodworks (SELF et al. 2002). According to Ferreira (1979), the species can also be used in production of plywood, boxes, posts, beams, stakes, and civil construction. Paes (2002) rated $C$. maculata wood as being resistant to fungi and termite attack, nevertheless recommending conservation treatments where external use is intended. The species can also be used in reforestation and urban forestry programs due to its beautiful trunk and crown (LORENZI et al. 2003, METRO TREES 2009).

In areas of natural occurrence of the above species, differences have been noted between provenances regarding tolerance to frost, and studies involving species selection and improvement have been conducted by CSIRO researchers (ROB 2004). Its estimated that in areas with annual precipitation of $500 \mathrm{~mm}$, crops with a density of 150 trees/hectare will yield around $135 \mathrm{~m}^{3} / \mathrm{ha} /$ year of sawn timber in a span of 26 years (ROB 2004).

Coelho et al. (1976) tested nine species of family Myrtaceae (genera Corymbia and Eucalyptus) at five different locations in São Paulo State. In the evaluation, at age 3 years, best performing species in coping with edaphic and climatic conditions included: E. grandis, E. alba and C. maculata. Ferreira (1979) recommends planting $C$. maculata only at altitudes below 1,600 m.

Information on development and estimation of genetic parameters is much desired to help planning and accomplishing genetic improvement programs intended to increase productivity. In order to implement genetic improvement programs for populations of genera from family Myrtaceae, understanding genetic variation and genetic control of growth and form traits at the provenance and progeny levels is a critical step to facilitate identification of superior genotypes for composing seed orchards.

Given the above, this study aimed to investigate genetic variation and estimate genetic parameters at ages 4 and 21 years in a provenance-progeny test of $C$. maculate, conducted at Pederneiras Experimental Station, in São Paulo.

\section{MATERIAL AND METHODS}

\subsection{Provenance origin and experimental design}

The provenance-progeny test of Corymbia maculata was implemented in 1985, at Pederneiras Experimental Station, SP. It comprised 21 progenies from provenance Woondum St. Forest - Gympie (Queensland) and 17 progenies from provenance Wondai St. Forest (Queensland), as well as two controls obtained from Brazilian commercial crops. The geographic coordinates of provenances and of study site location are given in Table 1. A compact family block design was used (WRIGHT 1978) consisting of ten replicates, six plants per straight-line plot and two outer border rows mixing the two controls, with spacing $3 \times 2 \mathrm{~m}$.

The evaluation of quantitative traits was carried out at ages 4 and 21. Measurements included: DBH (diameter at breast height), total height $(h)$, stem form (ranging from 1-very twisted to 5-straight) and survival. Additionally, the individual cylindrical volume outside bark was calculated using the classic expression:

$$
V=\frac{\pi(D B H)^{2} h}{4}
$$

\subsection{Analyses of variance and estimation of variance components}

Analyses of variance were performed for each trait based on the Restricted Maximun Likelihood method (REML) for estimation of variance components, due to the experimental imbalance caused by the variable number of

Table 1 - Geographic coordinates of provenances and study site location.

Tabela 1 - Coordenadas geográficas das procedências e local de implantação do experimento.

\begin{tabular}{|c|c|c|c|c|}
\hline $\begin{array}{l}\text { Provenances and study } \\
\text { site }\end{array}$ & Latitude & Longitude & Altitude (m) & Precipitation $(\mathrm{mm})$ \\
\hline Woondum, QLD & $26^{\circ} 15^{\prime}$ & $159^{\circ} 49^{\prime}$ & 400 & 1,600 \\
\hline Wondai, QLD & $26^{\circ} 31^{\prime}$ & $151^{\circ} 86^{\prime}$ & 356 & -- \\
\hline Pederneiras, SP & $22^{\circ} 22^{\prime}$ & $48^{\circ} 44^{\prime}$ & 500 & 1,226 \\
\hline
\end{tabular}


surviving trees in subplots and variable number of progenies per provenance. The REML procedure was used combined with the VARCOMP procedure of statistical application SAS (SAS INSTITUTE 1999) for estimation of variance components. The following mixed linear model was adopted:

$$
Y_{i j k l}=m+b_{i}+t_{j}+f_{j k}+(t b)_{i j}+(f b)_{i j k}+e_{i j k l},
$$

where $Y_{i j k l}$ is the phenotypic value of the $l$-th individual of the $k$-th progeny of the $j$-th provenance in the $i$-th replicate, $m$ is the fixed term of the general mean, $b_{i}$ is the fixed effect of the $i$-th replicate, $t_{j}$ is the fixed effect of the $j$-th provenance, $f_{j k}$ is the random effect of the $k$-th progeny in the $j$-th provenance, $(t b)_{j i}$ is the random effect of interaction between the $j$-th provenance and $i$-th replicate, $(f b)_{i j k}$ is the random effect of interaction between the $k$-th progeny of the $j$-th provenance in the $i$-th replicate, and $e_{i j k l}$ is the effect of the $l$-th tree within the $k$-th progeny of the $j$-th provenance in the $i$-th replicate (error within); $i=1 \ldots b$ ( $b$ is the number of replicates, in the blocks case); $j=1 \ldots t$ ( $t$ is the number of provenances); $k=1 . . . f(f$ is the number of progenies within provenance); $1=1 \ldots n$ ( $n$ is the number of trees per progeny).

The following variance components were estimated: $\sigma_{p}^{2}=$ genetic variance among progenies within provenance, $\sigma_{e}^{2}=$ variance of interaction among blocks and progenies within provenance (environmental variance), and $\sigma_{d}^{2}=$ phenotypic variance within progenies. From these variance components the total phenotypic variance $\left(\hat{\sigma}_{F}^{2}=\hat{\sigma}_{d}^{2}+\hat{\sigma}_{e}^{2}+\hat{\sigma}_{p}^{2}\right)$ and additive genetic variance $\left(\hat{\sigma}_{A}^{2}=\hat{\sigma}_{p}^{2} / \hat{r}_{x y}\right)$ were estimated. The mean kinship coefficient within progenies $\left(r_{x y}\right)$ was calculated by:

$\hat{r}_{x y}=0.25\left(1+\hat{F}_{p}\right)\left[4 \hat{s}+\left(t^{2}+\hat{r}_{s} \hat{s} \hat{t}\right)\left(1+r_{p}\right)\right]$

(RITLAND 1989)

where $F_{p}$ is the endogamy coefficient in parental population (assumed to be zero), $S$ is the self-fertilization rate $(s=1-t), t$ is the outcrossing rate $(t=1-s), r_{s}$ is the correlation of self-fertilization (assumed to be zero), $r_{p}$ is the correlation of paternity. The outcrossing rate was assumed to be 0.75 , while the correlation of paternity was assumed to be 0.36 (SEBBENN et al. 2003).

\subsection{Estimation of genetic parameters}

Calculations of heritability coefficients, coefficients of genetic variation and correlations between traits followed Namkoong (1979). Heritability coefficients were estimated at individual plant level $\left(h_{i}^{2}\right)$, at progeny mean level $\left(h_{m}^{2}\right)$ and within progenies $\left(h_{d}^{2}\right)$ :

$$
\begin{gathered}
\hat{h}_{i}^{2}=\frac{\hat{\sigma}_{A}^{2}}{\hat{\sigma}_{p}^{2}+\hat{\sigma}_{e}^{2}+\hat{\sigma}_{d}^{2}} \\
\hat{h}_{m}^{2}=\frac{\hat{\sigma}_{A}^{2}}{\hat{\sigma}_{p}^{2}+\frac{\hat{\sigma}_{e}^{2}}{J}+\frac{\hat{\sigma}_{d}^{2}}{\bar{n} J}} \\
\hat{h}_{d}^{2}=\frac{\left(1-\hat{r}_{x y}\right) \hat{\sigma}_{A}^{2}}{\hat{\sigma}_{d}^{2}}
\end{gathered}
$$

where $J$ is the number of replicates, $\bar{n}$ is the harmonic mean of number of plants per subplot.

The coefficient of genetic variation $\left(C V_{g}\right)$ was estimated using the following expression:

$$
C V_{g}=\frac{\sqrt{\hat{\sigma}_{g}^{2}}}{\bar{x}} \times 100
$$

Genetic correlations between different traits in the same age range and between the same traits at different age ranges were estimated by the following equation:

$$
\hat{r}_{g_{X Y}}=\frac{\hat{\sigma}_{g_{X} g_{Y}}}{\sqrt{\hat{\sigma}_{g_{X}}^{2} \hat{\sigma}_{g_{Y}}^{2}}}
$$

where $\sigma_{g_{X} g_{Y}}$ is the genetic cross product of traits $x$ and $y$, estimated from analyses of covariance, $\sigma_{g_{X}}^{2}$ and $\sigma_{g y}^{2}$ are genetic variances of traits $x$ and $y$ respectively.

The expected response with sequential selection among and within progenies $\left(R_{e d}\right)$ was calculated by:

$$
\hat{R}_{e d}=i_{e} \hat{\sigma}_{F} \hat{h}_{m}^{2}+i_{d} \hat{\sigma}_{d} \hat{h}_{d}^{2}
$$

where $i_{e}$ and $i_{d}$ are selection intensities in standard deviation unit, applied among and within progenies, while $\sigma_{F}$ and $\sigma_{d}$ are standard deviations of total phenotypic variance and variance within progenies. For the assembly of a seedling seed orchard, 15 progenies were selected $\left(15: 38,37 \%-i_{e}=0.9838\right)$ (HALLAUER \& MIRANDA 1988) as well as the best tree within the best progenies (1:50: $\left.2 \%-i_{d}=2.4209\right)$ (HALLAUER \& 
MIRANDA 1988). The percentage response to selection [ $\hat{R}^{(\%)}$ ] was estimated by:

$$
\hat{R}(\%)=\frac{100 \hat{R}_{e d}}{\bar{x}}
$$

where $\bar{x}$ is the trait mean.

\section{RESULTS AND DISCUSSION}

\subsection{Variation between provenances and progenies}

Significant differences were detected by the $\mathrm{F}$ test of the analysis of variance between provenances and among progenies within provenances at age 4 for traits DBH and height (Table 2).

Also at age 4, significant differences were detected among progenies for variable volume. At age 21, the analysis of variance did not detect significant differences between provenances and progenies. These results indicate that, with development, different provenances and their relevant progenies started to present similar growth pattern and selection could be done ignoring the effect of provenance or progeny within provenance (mass selection).

\subsection{Growth of provenances}

The DBH and height development of C. maculata from the two provenances was similar in both age classes being assessed (Table 2), despite Wondai showing slightly superior growth. At age 21, both provenances outranked the two controls with regard to general and individual mean values of $\mathrm{DBH}$, height, volume and survival traits. The greatest difference was detected for volume, and the provenance with the lowest volume value-Woondumoutranked the best control by $15.6 \%$.

Mean annual increments (MAI) at age 21 (0.96 and 1.34 for DBH and height respectively) indicate good adaptation by the species to local edaphic and climatic conditions (Table 2). In comparing MAI values of growth traits for C. maculata to results for other species of the genus at similar ages, it was noted that the above species showed good height development and has potential for application in commercial reforestation in Pederneiras region. The height MAI for $C$. maculata was higher by around 20\% than the result for $E$. resinifera (SATO et al. 2007), and higher by $30 \%$ than the result for $E$. camaldulensis (MORAES et al. 2007). The DBH MAI was similar to the result obtained for E. camaldulensis and around $47 \%$ lower than the result for E. resinifera. Results obtained by Pasztor \& Coelho (1976) with provenances of C. maculata at age 7 are also very close to results obtained in this study at age 4 . Analyses performed after thinning at age 8 years detected a positive height response from $C$.

Table 2 - Probabilities of the $F$ test of the analysis of variance and mean values of growth, form and survival traits for provenances and progenies of $C$. maculata, at ages 4 and 21 years.

Tabela 2 - Probabilidades do teste $F$ da análise de variância e média dos caracteres de crescimento, forma e sobrevivência de procedências e progênies de C. maculata, aos quatro e 21 anos de idade.

\begin{tabular}{|c|c|c|c|c|c|c|c|c|c|}
\hline Source & $\begin{array}{c}\mathrm{DBH}_{4} \\
(\mathrm{~cm})\end{array}$ & $\begin{array}{c}\mathrm{DBH}_{21} \\
(\mathrm{~cm})\end{array}$ & $\begin{array}{l}\mathrm{HEI}_{4} \\
(\mathrm{~m})\end{array}$ & $\begin{array}{c}\mathrm{HEI}_{21} \\
(\mathrm{~m})\end{array}$ & $\begin{array}{c}\mathrm{VOL}_{4} \\
\left(\mathrm{~m}^{3} / \text { tree }\right)\end{array}$ & $\begin{array}{c}\mathrm{VOL}_{21} \\
\left(\mathrm{~m}^{3} / \text { tree }\right)\end{array}$ & $\begin{array}{c}\mathrm{SUR}_{4} \\
(\%)\end{array}$ & $\begin{array}{c}\mathrm{SUR}_{21} \\
(\%)\end{array}$ & $\mathrm{FOR}_{21}$ \\
\hline Block & 0.0001 & 0.1659 & 0.0001 & 0.6067 & 0.0001 & 0.3771 & 0.0001 & 0.0001 & 0.1856 \\
\hline Provenance & 0.0113 & 0.2763 & 0.0003 & 0.1201 & 0.0812 & 0.5468 & 0.6145 & 0.5991 & 0.2917 \\
\hline Progenies & 0.0135 & 0.1111 & 0.0001 & 0.0816 & 0.0051 & 0.3142 & 0.4198 & 0.2856 & 0.3183 \\
\hline \multicolumn{10}{|l|}{ General } \\
\hline Mean & 7.59 & 20.24 & 7.69 & 28.21 & 0.0486 & 1.2300 & 69.9 & 61.6 & 3.47 \\
\hline Woondum & 7.39 & 20.06 & 7.49 & 27.93 & 0.0471 & 1.2275 & 71.0 & 62.0 & 3.49 \\
\hline Wondai & 7.83 & 20.47 & 7.92 & 28.57 & 0.0514 & 1.2465 & 69.0 & 61.6 & 3.44 \\
\hline Controls & 7.31 & 18.79 & 7.62 & 26.90 & 0.0441 & 1.0240 & 67.5 & 58.2 & 3.45 \\
\hline Control 1 & 7.20 & 18.99 & 7.50 & 26.55 & 0.0420 & 1.0356 & 63.3 & 55.8 & 3.48 \\
\hline Control 2 & 7.42 & 18.56 & 7.74 & 27.28 & 0.0462 & 1.0115 & 71.6 & 60.6 & 3.41 \\
\hline Mean MAI & 1.90 & 0.96 & 1.92 & 1.34 & 0.01 & 0.06 & & & -- \\
\hline
\end{tabular}

MAI $=$ Mean annual increment, DBH $=$ diameter at breast height $(\mathrm{cm}), \mathrm{HEI}=$ total height of plant $(\mathrm{m}), \mathrm{VOL}=\mathrm{volume}\left(\mathrm{cm}^{3}\right)$, SUR $=$ survival $(\%)$, FOR $=$ stem form ${ }_{4}=$ age assessed (years) ${ }_{21}=$ age assessed (years). 
maculata, with a MAI value of $2.35 \mathrm{~m}$ (PASZTOR \& COELHO 1976).

Although no significant differences were detected for trait stem form, the mean value of the two provenances can be considered high at age 21 (3.47), and that reinforces the species potential for sawn wood production in Pederneiras region, SP.

\subsection{Genetic variation and heritabilities}

At age 21, the crop revealed high phenotypic variance among plants from within progenies $\left(\sigma_{d}^{2}\right)$, for $\mathrm{DBH}$ and height (63.97 and 58.13 respectively). This variance component is composed of at least $3 / 4$ of additive genetic variance among individuals from within progenies (in the case of half-sib progenies), indicating that gains can be achieved through selection of best trees within best progenies. These values are much higher than values found by Ettori et al. (2004) for Pinus maximinoi (DBH = 33.69 and height $=3.70)$, by Freitas et al. $(2005)$ for $P$. caribaea bahamensis $(\mathrm{DBH}=26.7$ and height $=4.57)$, by Sebbenn et al. (2005) for $P$. patula tecunumanii $(\mathrm{DBH}=$ 23.02 and height $=7.60$ ) and by Sato et al. (2007) for $E$. resinifera $(\mathrm{DBH}=37.16$ and height $=22.99)$.

The estimated coefficient of genetic variation $(\mathrm{CVg})$ (Table 3) was low for all traits being assessed, yet an increase was observed at age 21 , suggesting that improved genetic gains can be achieved for older age selection. In comparing CVg values to other species (Table 4), height values were noted to be very similar to height values obtained for the two Eucalyptus species and relatively higher than for other species, though volume values were much lower than for other species.

The estimated heritability coefficients at individual plant level $\left(h_{i}^{2}\right)$ and within progenies $\left(h_{d}^{2}\right)$ were low for both age classes and for all traits being assessed, suggesting limited genetic control over traits and also that little genetic progress can be expected from mass selection within the experiment and among plants from within progenies. Heritability coefficient values at the progeny mean level $\left(h_{m}^{2}\right)$ were anyhow median at age 21 , with values $0.21,0.34$ and 0.40 for volume, DBH, and height respectively. The same behavior, with greater genetic control as age advances, was reported for Pinus maximinoi (ETTORI et al. 2004), $P$. caribaea bahamensis (FREITAS et al. 2005), P. patula tecunumanii (SEBBENN et al. 2005) and E. resinifera (SATO et al. 2007). By contrast, Moraes et al. (2007) found much higher heritability values for $E$. camaldulensis that ranged from 0.73 to 0.80 , an indication of high genetic control of traits at the progeny level. Overall, results indicate that genetic gains can be achieved through selection of best progenies and best plants within progenies for traits $\mathrm{DBH}$, height and volume, given the higher $\mathrm{CVg}$ and $h_{m}^{2}$ values.

Table 3 - Estimation of genetic parameters in progenies of $C$. maculata at ages 4 and 21.

Tabela 3 - Estimativa de parâmetros genéticos em progênies de C. maculata, aos 4 e 21 anos de idade.

\begin{tabular}{lccccccccc}
\hline Parameters & $\mathrm{DBH}_{4}$ & $\mathrm{DBH}_{21}$ & $\mathrm{HEI}_{4}$ & $\mathrm{HEI}_{21}$ & $\mathrm{VOL}_{4}$ & $\mathrm{VOL}_{21}$ & $\mathrm{SUR}_{4}$ & $\mathrm{SUR}_{21}$ & $\mathrm{FOR}_{21}$ \\
\hline$\sigma_{p}^{2}$ & 0.0212 & 0.6885 & 0.0639 & 0.9570 & 0.00004 & 0.0076 & 0.00003 & 0.00020 & 0 \\
$\sigma_{e}^{2}$ & 1.1308 & 0.3286 & 1.1639 & 2.3114 & 0.00020 & 0.0113 & 0.01769 & 0.01923 & 0.0040 \\
$\sigma_{d}^{2}$ & 7.9455 & 63.9717 & 4.2837 & 58.1332 & 0.00150 & 1.2935 & -- & -- & 0.0626 \\
$\mathrm{CVg}(\%)$ & 0.28 & 3.40 & 0.83 & 3.39 & 0.01 & 0.62 & 0.00 & 0.03 & - \\
$h_{i}^{2}$ & 0.0053 & 0.0240 & 0.0262 & 0.0353 & 0.0062 & 0.0131 & -- & -- & - \\
$h_{m}^{2}$ & 0.0723 & 0.3441 & 0.2403 & 0.4071 & 0.0891 & 0.2196 & 0.0184 & 0.09612 & - \\
$h_{d}^{2}$ & 0.0034 & 0.0136 & 0.0188 & 0.0208 & 0.0038 & 0.0074 & -- & -- & - \\
$\mathrm{G}_{\text {ed }}$ & 0.2377 & 2.9923 & 0.6493 & 3.5218 & 0.0040 & 0.2679 & 0.0024 & 0.0132 \\
$\mathrm{G}_{\mathrm{ed}}(\%)$ & 3.13 & 14.78 & 8.45 & 12.48 & 8.17 & 21.77 & 0.34 & 2.14 & - \\
\hline
\end{tabular}

$\mathrm{DBH}=$ diameter at breast height $(\mathrm{cm}), \mathrm{HEI}=$ total height $(\mathrm{m}), \mathrm{VOL}=$ volume $\left(\mathrm{cm}^{3}\right), \mathrm{SUR}=$ survival $(\%), \mathrm{FOR}=$ stem form, ${ }_{4}=\mathrm{age}$ assessed (years), ${ }_{21}=$ age assessed (years), $\mathrm{G}_{\mathrm{ed}}=$ gains among and within.

Selection intensity within progenies: 1:50 (2\%), selection intensity among progenies (39\%): 15:38.

Cerne, Lavras, v. 16, n. 1, p. 60-67, jan./mar. 2010 


\subsection{Correlation between traits, among and within age classes}

Genetic correlations in the same age class, between different growth traits, were positive and significant for DBH, height and volume (Table 5), indicating the possibility of making indirect genetic gains by selecting any such traits.

Additionally, correlations between growth traits and survival at ages 4 and 21 years were also significant, positive and high, suggesting that early selection at age 4 could have been made. In other words, this means that most progenies being selected at age 4 years would be the same progenies being selected today.

\subsection{Gains estimated by selection among and within progenies}

In this study, expected gains from selection were calculated by assuming a selection intensity of $39 \%$ among and $2 \%$ within progenies (Table 3 ). Greater gains were observed at age 21. Expected genetic gains from selection among and within progenies indicate greater gains for trait volume (21.77\%), followed by DBH (14.78\%) and height (12.48\%). Results obtained by Sato et al. (2007) for $E$. resinifera also indicate that greater gains will be made through selection for volume, DBH and height, despite at much lower percentages $(4.9 \%, 0.77 \%$ and $0.74 \%$

Table 4 - Coefficient of genetic variation $(\mathrm{CVg})$ and heritability at the progeny mean level $\left(h_{m}^{2}\right)$ for traits DBH, height, form and volume for some forest species.

Tabela 4 - Coeficiente de variação genética $(C V g)$ e herdabilidade em nível de média e progênies $\left(h_{m}^{2}\right)$ para os caracteres DAP, altura, forma e volume de algumas espécies florestais.

\begin{tabular}{|c|c|c|c|c|c|c|c|c|c|c|}
\hline \multirow[b]{2}{*}{ Species } & \multirow[b]{2}{*}{ Age (years) } & \multicolumn{2}{|c|}{$\mathrm{DBH}(\mathrm{cm})$} & \multicolumn{2}{|c|}{ Height (m) } & \multicolumn{2}{|c|}{ Form } & \multicolumn{2}{|c|}{ Volume } & \multirow[b]{2}{*}{ Source } \\
\hline & & $\mathrm{CVg}$ & $h_{m}^{2}$ & $\mathrm{CVg}$ & $h_{m}^{2}$ & $\mathrm{CVg}$ & $h_{m}^{2}$ & $\mathrm{CVg}$ & $h_{m}^{2}$ & \\
\hline Balfourodendron riedelianum & 21 & 3.98 & 0.29 & 1.02 & 0.14 & 0.36 & 0.01 & 9.04 & 0.33 & Sebbenn et al. (2007) \\
\hline Cordia trichotoma & 19 & 11.48 & 0.77 & 2.33 & 0.12 & 2.90 & 0.46 & 14.51 & 0.65 & Freitas et al. (2006) \\
\hline Pinus caribaea bahamensis & 22 & 2.77 & 0.28 & 1.90 & 0.45 & 3.26 & 0.40 & 6.80 & 0.40 & Freitas et al. (2005) \\
\hline Eucalyptus camaldulensis & 19 & 5.39 & 0.72 & 3.36 & 0.73 & 8.80 & 0.80 & -- & -- & Moraes et al. (2007) \\
\hline Eucalyptus resinifera & 21 & 2.60 & 0.55 & 3.00 & 0.37 & -- & -- & 12.1 & 0.59 & Sato et al. (2007) \\
\hline Corymbia maculata & 21 & 3.40 & 0.34 & 3.39 & 0.41 & -- & -- & 0.62 & 0.22 & This study \\
\hline
\end{tabular}

Table 5 - Genetic correlations between different traits in the same age class and between same traits in different age classes in progenies of C. maculata.

Tabela 5 - Correlações genéticas entre diferentes caracteres em mesma idade e entre mesmos caracteres em diferentes idades em progênies de C. maculata.

\begin{tabular}{|c|c|c|c|c|c|c|}
\hline & $\mathrm{HEI}_{4}$ & $\mathrm{VOL}_{4}$ & $\mathrm{DBH}_{21}$ & $\mathrm{HEI}_{21}$ & $\mathrm{VOL}_{21}$ & $\mathrm{SUR}_{21}$ \\
\hline $\mathrm{DBH}_{4}$ & $1.00 * *$ & $1.00 * *$ & $1.00 * *$ & -- & -- & -- \\
\hline $\mathrm{HEI}_{4}$ & & $1.00 * *$ & -- & $0.82 * *$ & -- & -- \\
\hline $\mathrm{VOL}_{4}$ & & & & -- & $0.66 *$ & -- \\
\hline $\mathrm{DBH}_{21}$ & & & & $1.00 * *$ & $0.99 * *$ & -- \\
\hline $\mathrm{HEI}_{21}$ & & & & & $0.99 * *$ & -- \\
\hline $\mathrm{SUR}_{4}$ & & & & & & $0.88 * *$ \\
\hline
\end{tabular}


respectively). Greater expected gains through selection for trait volume were also reported for Pinus caribaea bahamensis (FREITAS et al. 2005) and Cordia trichotoma (FREITAS et al. 2006). For Araucaria angustifolia (SEBBENN et al. 2003), better gains were observed through selection for DBH, followed by height and volume. Overall, results indicated that, although at age 21 genetic variations among progenies and heritability coefficients were relatively low, gains can be achieved if high selection intensity is applied among and within progenies. Finally, it should be noted that these gains refer to crops aged 21 years and under similar conditions to Pederneiras Experimental Station, with seeds deriving from a recombination of the trees selected in this study.

\section{CONCLUSIONS}

It can be said from results that it is possible to apply selection for one trait and obtain indirect gains with another trait in the same age class. In addition, it is possible to apply early selection at age 4 and make gains at age 21 .

Even there being no significant differences between provenances and progenies, and heritabilities being relatively low, the application of high selection intensity among and within progenies can result in gains.

\section{ACKNOWLEDGMENTS}

The authors wish to thank Francisco Bianco for helping with data collection; and Mr. Adolpho Dário for providing information and helping locate and conduct experiments. The authors also wish to thank three revisors for their suggestions and corrections to the relevant manuscript.

\section{BIBLIOGRAPHICAL REFERENCES}

COELHO, L. C. C.; MOURA NETO, B. V. de; GIANNOTTI, E.; ASSINI, J. L.; MORAES, J. L. de; FAGUNDES, M. de A.; FERNANDES, P. de S.; SOUZA, W. J. M. Experimentação com nove espécies de Eucalyptus em várias Regiões do Estado de São Paulo. Silvicultura em São Paulo, São Paulo, n. 10, p. 125135, 1976.

ETTORI, L. C.; SATO, A. S.; SHIMIZU, J. Y. Variação genética em procedências e progênies mexicanas de Pinus maximinoi. Revista do Instituto Florestal, São Paulo, v. 16, n. 1, p. 1-9, 2004.

FERREIRA, M. Escolha de espécies de eucalipto. IPEF, Piracicaba, v. 47, p. 1-30, 1979.

Cerne, Lavras, v. 16, n. 1, p. 60-67, jan./mar. 2010
FREITAS, M. L. M.; SEBBENN, A. M.; MORAIS, E.; ZANATTO, A. C. S.; SOUSA, C. M. R.; LEMOS, S. V. Parâmetros genéticos em progênies de polinização aberta de Pinus caribaea var. bahamensis, aos 22 anos de idade. Revista do Instituto Florestal, São Paulo, v. 17, n. 1, p. 103-111, 2005.

FREITAS, M. L. M.; SEBBENN, A. M.; MORAIS, E.; ZANATTO, A. C. S.; VERARDI, C. K.; PINHEIRO, A. N. Parâmetros genéticos em progênies de polinização aberta de Cordia trichotoma (Vell.) ex Steud. Revista do Instituto Florestal, São Paulo, v. 18, p. 95-102, 2006.

HALLAUER, A. R.; MIRANDA, J. B. Quantitative genetics in maize breeding. Ames: Iowa State University, 1988. 468 p.

LORENZI, H.; SOUZA, H. M.; TORRES, M. A. V.; BACHER, L. B. Árvores exóticas no Brasil: madeireiras, ornamentais e aromáticas. Nova Odessa: Instituto Plantarum, 2003. 368 p.

METRO TREES. Corymbia (Eucalyptus) maculata. Disponível em: $\langle\mathrm{h}$ ttp: ///www.metrotrees.com.au/treehandbooki page-listings/corymbia-eucalyptus-maculata.htmly. Acesso em: 22 abr. 2009.

MORAES, M. A.; ZANATTO, A. C. S.; MORAES, E.; SEBBENN, A. M.; FREITAS, M. L. M. Variação genética para caracteres silviculturais em progênies de polinização aberta de Eucalyptus camaldulensis em Luiz Antonio - SP. Revista do Instituto Florestal, São Paulo, v. 19, n. 1, p. 93-100, 2007.

NAMKOONG, G. Introduction to quantitative genetics in forestry. Washington: United States Forest Service, 1979. 342 p. (Technical Bulletin, 1588).

PAES, J. B. Resistência natural da madeira de Corymbia maculata (Hook.) K.D. Hill \& L.A.S. Johnson a fungos e cupins xilófagos, em condições de laboratório. Revista Árvore, Viçosa, v. 26, n. 6, p. 761-767, 2002.

PÁSZTOR, Y. P. de C.; COELHO, L. C. C. Ensaio de Procedências de Eucalyptus maculata Hook: resultados preliminares. Silvicultura em São Paulo, São Paulo, n. 10, p. 65-71, 1976.

PEREIRA, J. C. D.; STURION, J. A.; HIGA, A. R.; HIGA, R. C. V.; SHIMIZU, J. Y. Características da madeira de algumas espécies de eucalipto plantadas no Brasil. Colombo: Embrapa Florestas, 2000. 113 p. (Embrapa Florestas. Documentos, 38). 
RITLAND, K. Correlated matings in the partial selfer Mimulus guttatus. Evolution, San Francisco, v. 43, p. 848-859, 1989.

ROB, C. Spotted gum (Corymbia maculata) for sawlogs in the 450-650 mm rainfall zone. Farmnote: Department of Agriculture, Western Australia, 2004. Disponível em: <http:// Www.agric.wa.gov.au/content/fcp/sc/tree/fn 059_2004.pdf Acesso em: 22 abr. 2009.

SAS INSTITUTE. SAS procedures guide. Version 8. Cary, 1999. $454 \mathrm{p}$.

SATO, A. S.; SEBBENN, A. M.; MORAES, E.; ZANATTO, A. C. S.; FREITAS, M. L. M. Seleção dentro de progênies de Eucalyptus resinifera aos 21 anos de idade em Luiz Antonio - SP. Revista do Instituto Florestal, São Paulo, v. 19, n. 1, p. 93-100, 2007.

SEBBENN, A. M.; FREITAS, M. L. M.; MORAIS, E.; ZANATTO, A. C. S. Variação genética em procedências de Pinus patula ssp. tecunumanii no noroeste do Estado de São Paulo. Revista do Instituto Florestal, São Paulo, v. 17, n. 1, p. 1-15, 2005.
SEBBENN, A. M.; FREITAS, M. L. M.; ZANATTO, A. C. S.; MORAES, E.; MORAES, M. A. Conservação ex situ e pomar de sementes em banco de germoplasma de Balfourodendron riedelianum. Revista do Instituto Florestal, São Paulo, v. 19, n. 1, p. 101-112, 2007.

SEBBENN, A. M.; PONTINHA, A. A. S.; GIANNOTTI, E.; KAGEYAMA, P. Y. Variação genética entre e dentro de procedências e progênies de Araucaria angustifolia no sul do Estado de São Paulo. Revista do Instituto Florestal, São Paulo, v. 15, n. 2, p. 109-124, 2003.

SELF, N. M.; AITKEN, E. A. B.; DALE, M. D. Susceptibility of provenances of spotted gums to Ramularia shoot blight. New Zealand Plant Protection, Wellington, n. 55, p. 68-72, 2002.

WRIGHT, J. W. A simplified design for combined provenance and progeny testing. Silvae Genetica, Frankfurt, v. 27, n. 2, p. 68-70, 1978. 